\title{
ANALISIS PERLAKUAN AKUNTANSI AKTIVITAS AGRIKULTUR DALAM PENYAJIAN LAPORAN KEUANGAN BERDASARKAN PSAK 69 PADA PT IJ
}

\author{
Fathi Maurits Muhamada \\ fathi.maurits@gmail.com \\ Universitas Pembangunan Nasional "Veteran" Jakarta
}

\begin{abstract}
Abstrak
Aktivitas agrikultur merupakan jenis kegiatan operasi yang dilakukan oleh entitas untuk memanajemen transformasi biologis dan panen aset biologis untuk dijual atau dikonversi menjadi produk agrikultur. Dalam transformasi biologis diperlukan pengukuran yang menunjukkan nilai dari aset biologis secara wajar sesuai dengan manfaat ekonomis bagi entitas. PSAK 69 mengenai agrikultur telah disahkan oleh Dewan Standar Akuntansi Keuangan Ikatan Akuntan Indonesia (DSAK IAI) dan penerapannya berlaku efektif sejak 1 Januari 2018. PSAK 69 Agrikultur mengatur perlakuan akuntansi serta pengungkapan yang terkait dengan aktivitas agrikultur. Penelitian ini dilakukan dengan tujuan untuk mengetahui perlakuan akuntansi atas aktivitas agrikultur serta penerapan PSAK 69 pada PT IJ yang merupakan salah satu entitas yang kegiatan usahanya bergerak dalam pengusahaan hutan tanaman industri. Penelitian ini menggunakan metode penelitian kualitatif dengan paradigma interpretif dan pendekatan etnometodologi. Teknik analisis data yang digunakan pada saat pengumpulan data berupa observasi, wawancara kepada informan serta dengan mengumpulkan dokumen berupa laporan keuangan sebagai data pendukung penelitian. Berdasarkan penelitian yang dilakukan, hasil pembahasan menunjukkan bahwa perlakuan akuntansi atas aktivitas agrikultur pada PT IJ secara pengakuan, pengukuran, pencatatan, penyajian, dan pengungkapan telah sesuai dengan PSAK 69 tentang agrikultur.
\end{abstract}

Kata Kunci: Perlakuan Akuntansi; Aktivitas Agrikultur; dan PSAK 69

\begin{abstract}
Agricultural activity is a type of operational activity carried out by an entity to manage biological transformation and harvest biological assets to be sold or converted into agricultural products. In biological transformation a measurement is needed which shows the value of a biological asset in fair value with the economic benefits for the entity. PSAK 69 concerning agriculture has been approved by the Indonesian Financial Accounting Standards Board (DSAK IAI) and its application is effective from 1 January, 2018. PSAK 69 Agriculture regulates the accounting treatment and disclosures related to agricultural activities. This research was conducted with the aim of knowing the accounting treatment of agricultural activities and the application of PSAK 69 to PT IJ which is one of the entities whose business activities are engaged in the exploitation of industrial plantations. This study used qualitative research methods with interpretive paradigms and ethnometodology approaches. Data analysis techniques used at the time of data collection in the form of observations, interviews with informants and by collecting documents in the form of financial statements as supporting data research. Based on the research conducted, the results of the discussion show that the accounting treatment of agricultural activities at PT IJ in recognition, measurement, recording, presentation and disclosure is in accordance with PSAK 69 concerning agriculture.
\end{abstract}


Keywords: Accounting Treatment; Agricultural Activities; andPSAK 69

\section{PENDAHULUAN}

Usaha dibidang Industri pertanian saat ini sedang mengalami perkembangan yang cukup pesat. Beberapa faktor yang dapat mempengaruhi perkembangan tersebut, seperti perkembangan pada teknologi pertanian yang semakin mutakhir dan canggih, bertambahnya permintaan hasil pertanian, adanya era perekonomian baru yaitu pasar bebas ASEAN dan timbulnya otonomi daerah yang memiliki dampak pada pengelolaan hasil dari pertanian. Selain itu, semakin meningkat tuntutan transparansi dan juga akuntabilitas oleh publik yang seiring dengan berkembangnya keterbukaan atas informasi yang telah difasilitasi oleh keberadaan dari teknologi komunikasi dan informasi yang terus semakin berkembang dengan berbagai kemudahan yang diberikan.

Oleh karena itu, industri pertanian sangat membutuhkan sebuah alat untuk memanajemen yang berguna dalam pengambilan keputusan. Contoh dari alat manajemen yang umumnya diketahui dan digunakan dapat berupa laporan keuangan. Kebutuhan akan laporan keuangan juga sangatlah vital bagi berbagai pihak, sebagai contoh, dibutuhkan oleh manajemen untuk menentukan langkah yang diambil dalam membuat keputusan ekonomi perusahaan, laporan keuangan juga dibutuhkan oleh investor untuk menilai apakah di masa mendatang perusahaan akan mendatangkan keuntungan bagi mereka.

Secara umum, dapat ditarik kesimpulan bahwa sebuah laporan keuangan dapat dikatakan baik jika dapat memberikan informasi yang andal, lengkap, dapat dibandingkan, dan relevan. Mengingat begitu pentingnya peran yang diberikan laporan keuangan, maka sudah menjadi kewajiban bagi entitas untuk melakukan penyusunan laporan keuangan dengan benar, baik, wajar dan sesuai dengan standar yang telah ditetapkan. Hal ini dibutuhkan sebagai bentuk untuk mengurangi terjadinya asimetri informasi atau perbedaan informasi yang diterima oleh kalangan pengguna laporan keuangan. Sehingga dalam melakukan penyusunan laporan keuangan, pemilihan dan penggunaan metode dan kebijakan akuntansi menjadi hal yang perlu diperhatikan. Metode dan kebijakan akuntansi yang digunakan harus disesuaikan dengan jenis usaha industri yang dijalankan oleh entitas tersebut. Keberagaman jenis usaha industri dan skala dari kegiatan entitas dapat menyebabkan berbedaan pada pemilihan dan penggunaan metode serta kebijakan akuntansi. Pada beberapa jenis industri yang mempunyai perbedaan karakteristik tertentu, perbedaan penggunaan kebijakan dan metode akuntansi sangat mungkin terjadi. Keunikan yang dimiliki oleh industri tersebut bisa terdapat pada kebijakan akuntansi, perlakuan akuntansi atas aset, struktur permodalan, pengelolaan dari produk yang diolah entitas, atau hal lainnya.

Aset yang dimiliki oleh perusahaan dibidang industri pertanian mempunyai karakteristik yang unik, berbeda dengan perusahaan yang bergerak dibidang industri lain. Perbedaan karakteristik tersebut dapat terlihat dari aktivitas pengelolaan dan juga transformasi biologis yang terjadi pada tanaman untuk menghasilkan suatu aset lainnya atau produk yang dapat digunakan langsung atau dapat diolah lebih lanjut. Pada umumnya, karena memiliki karakteristik yang unik, perusahaan yang bergerak dalam bidang kehutanan dan bidang perkebunan memiliki sebuah kemungkinan yang cukup besar untuk menyampaikan informasi pada laporan keuangan menjadi lebih bias dibandingkan dengan perusahaan yang dibidang lainnya terutama dalam hal pengakuan, pengukuran, pencatatan, penyajian dan pengungkapan mengenai aset tetap yang dimiliki oleh perusahaan. Namun, perusahaan yang bergerak pada bidang industri pertanian memiliki aset yang mempunyai karakteristik unik, aset tersebut adalah aset biologis. 
Definisi pada PSAK 69 aset biologis adalah hewan atau tanaman hidup. Namun makna tersebut berbenturan dengan definisi tanaman produktif yang masuk ke dalam lingkup dari PSAK 16 yang mengenai aset tetap, sehingga hal yang dimaksud disini adalah produk yang tumbuh pada tanaman produktif. Pada industri pertanian, aset menjadi salah satu bagian yang cukup menarik perhatian. Berbeda dengan perusahaan manufaktur pada umumnya, perusahaan yang bergerak dibidang industri pertanian memiliki aset yang berbentuk makhluk hidup (hewan dan tumbuhan). Proses perlakuan akuntansi mulai dari pengakuan, pengukuran, pencatatan, penyajian dan pengungkapan atas aset yang umumnya benda mati. Dibutuhkan pemahaman yang lebih mendetail terhadap aset biologis, karena terdapat klasifikasi yang berbeda pada PSAK 69 mengenai Agrikultur yang merupakan sebuah standar unik, jika standar yang lain memiliki klasifikasi aset berupa gedung, mesin, kendaraan, dan lain-lain, PSAK 69 justru merupakan standar yang mengatur tentang perlakuan akuntansi terhadap aset biologis (tanaman atau hewan hidup) serta produk agrikultur yang dimiliki oleh entitas.

Keberadaan dari PSAK 69 memiliki tujuan untuk mengatur perlakuan akuntansi yang dilakukan oleh entitas ketika berkaitan dengan aktivitas agrikultur. Aktivitas agrikultur sendiri merupakan kegiatan entitas untuk memanajemen proses pertumbuhan, penurunan, produksi, dan juga proses prokreasi yang memicu adanya perubahan dari segi kuantitatif maupun kualitatif aset biologis dan merupakan panen dari aset biologis yang dimiliki oleh entitas untuk dijual atau untuk di jadikan aset biologis tambahan.

Penerapan standar baru tentang agrikultur di Indonesia bisa menimbulkan kesulitan bagi perusahaan yang perlu menerapkannya, dimana aturan tersebut merupakan pengadopsian dari pengaturan internasional yang berkemungkinan hal tersebut belum tentu sepenuhnya dapat diterapkan perusahaan yang usahanya berkaitan dengan agrikultur di Indonesia. Dampak dari penerapan PSAK 69 yang efektif per tanggal 1 Januari 2018, maka perusahaan perlu melakukan adaptasi dengan peraturan tersebut. Sehingga perlu adanya penyesuaian yang dilakukan perusahaan dalam penerapannya. Perusahaan harus teliti dalam mengukur, mengakui, menyajikan, dan mengungkapkan hal-hal yang diatur dalam PSAK 69 agar dapat memberikan laporan keuangan yang andal, relevan, mudah dipahami, dan dapat dibandingkan. Penerapan aturan baru membuat PT. IJ mengalami kendala dalam melaksanakannya, terutama pada pengakuan yang perlu dilakukan untuk produk agrikulturnya, terutama pada produk getah karet. Hal tersebut dikarenakan oleh getah karet merupakan hasil agrikultur yang berada dalam tanaman produktif, sehingga cukup sulit untuk mengetahui besaran nilai pada produk tersebut. Selain itu, terdapat juga kendala dari sisi pengukuran dengan nilai wajar yang menggunakan nilai pada pasar aktif.

Menentukan nilai wajar dari aset atau liabilitas yang dimiliki memerlukan pengukuran yang berbasiskan pasar aktif dari komoditas yang ingin dijual atau ingin dimiliki, sehingga dengan menggunakan nilai wajar dapat mengestimasi dimana transaksi teratur untuk menjual aset atau mengalihkan liabilitas yang terjadi antara pelaku pasar pada tanggal pengukuran. Pengukuran terhadap aset biologis yang dilakukan menggunakan nilai wajar terkadang mengalami kendala, terutama ditahun pertama aset biologis tersebut diakui oleh entitas. Penilaian terhadap aset biologis pada tahun pertamanya setelah dilakukannya penanaman memang sangat memungkinkan untuk mengalami kerugian, karena aset biologis tersebut tentunya akan lebih banyak mengeluarkan biaya dan dianggap belum layak untuk dijual sehingga apabila terdapat nilai pada tanaman pun tidak akan melebihi biaya yang telah dikeluarkan oleh entitas. 


\section{TINJAUAN PUSTAKA}

\section{Aktivitas Agrikultur}

Aktivitas agrikultur merupakan suatu kegiatan yang dilakukan oleh entitas berupa pengelolaan dan pembudidayaan tanaman atau tumbuhan yang dimiliki oleh entitas dan akan memberikan manfaat di masa mendatang. Menurut Pernyataan Standar Akuntansi Keuangan (PSAK) No. 69 tentang agrikultur, aktivitas agrikultur adalah membantu memanajemen transformasi biologis dan panen aset biologis yang dilakukan oleh entitas untuk dijual atau untuk dikonversi menjadi produk agrikultur atau dijadikan sebagai aset biologis tambahan bagi entitas.(Ikatan Akuntan Indonesia, 2015)

Adapula pengertian aktivitas agrikultur dari International Accounting Standards (IAS) 41 yaitu "Agricultural activity is the management by an entity of the biological transformation and harvest of biological assets for sale or for conversion into agricultural produce or into additional biological assets".(International Accounting Standards Board, 2016) Sehingga dapat disimpulkan bahwa aktivitas agrikultur adalah manajemen yang dilakukan oleh perusahaan untuk mentransformasikan biologis dan juga untuk melakukan panen terhadap aset biologis yang dimiliki oleh perusahaan, entah untuk dijual sebagai produk dari perusahaan maupun dijadikan sebagai aset biologis tambahan bagi perusahaan.

Aktivitas agrikultur mencakup berbagai macam aktivitas yang meliputi peternakan, budidaya kebun dan perkebunan, kehutanan, budidaya ikan, budidaya bunga, tanaman semusim atau tahunan, dan juga kehutanan, maka dari itu terdapat pula karakteristik umum tertentu yang membahas keanekaragaman tersebut, dimana hal tersebut diungkapkan dalam PSAK 69, yaitu: 1. Kemampuan untuk berubah. Hewan dan tanaman hidup mampu melakukan transformasi biologis; 2. Manajemen perubahan. Manajemen mendukung transformasi biologis dengan meningkatkan, atau setidaknya menstabilkan, kondisi yang diperlukan agar proses tersebut dapat terjadi (sebagai contoh, tingkat nutrisi, kelembaban, temperatur, kesuburan, dan cahaya). Manajemen seperti ini membedakan aktivitas agrikultur dari aktivitas lain. Sebagai contoh, proses ganti hasil panen dari sumber yang tidak dikelola bukan merupakan aktivitas agrikultur (seperti penangkapan ikan laut dan penebangan hutan); dan 3. Pengukuran perubahan. Perubahan dalam kualitas (sebagai contoh, keunggulan genetik, kepadatan, kematangan, kadar lemak, kadar protein, dan kekuatan serat) atau kuantitas (sebagai contoh, keturunan, berat, meter kubik, panjang atau diameter serat, dan jumlah tunas) yang dihasilkan oleh transformasi biologis atau panen diukur dan dipantau sebagai fungsi manajemen yang rutin.

\section{Aset Biologis}

Aset biologis merupakan jenis aset berupa hewan dan tanaman hidup, seperti yang didefinisikan dalam IAS 41: “A biological asset is a living animal or plant."(International Accounting Standards Board, 2016)Aset biologis ini adalah aset yang dimiliki oleh entitas berupa tanaman dan atau hewan. Sebagaimana aset yang pada umumnya memiliki karakteristik, maka aset biologis ini pun juga merupakan hasil dari peristiwa ekonomi yang dilakukan entitas pada masa lalu, dikendalikan atau dimiliki sepenuhnya oleh entitas, dan juga diharapkan akan memberikan manfaat bagi entitas di masa mendatang.Berikut adalah tabel yang terdapat pada PSAK No. 69 yang menyajikan contoh dari aset biologis, produk agrikultur dan juga produk yang merupakan hasil pemrosesan setelah panen. 
Tabel 1. Contoh aset biologis, produk agrikultur dan juga produk yang merupakan hasil pemrosesan setelah panen

\begin{tabular}{lll}
\hline Aset biologis & Produk agrikultur & $\begin{array}{l}\text { Produk hasil pemrosesan } \\
\text { setelah panen }\end{array}$ \\
\hline Domba & Wol & Benang, karpet \\
\hline Pohon dalam hutan kayu & Pohon tebangan & $\begin{array}{l}\text { Kayu gelondongan, potongan } \\
\text { kayu }\end{array}$ \\
\hline Sapi perah & Susu & Keju \\
\hline Babi & Daging potong & Sosis, ham (daging asap) \\
\hline Tanaman kapas & Kapas panen & Benang, pakaian \\
\hline Tebu & Tebu panen & Gula \\
\hline Tanaman tembakau & Daun tembakau & Tembakau \\
\hline Tanaman teh & Daun teh & Teh \\
\hline Tanaman anggur & Buah anggur & Minuman anggur (wine) \\
\hline Tanaman buah-buahan & Buah petikan & Buah olahan \\
\hline Pohon kelapa sawit & Tandan buah segar & Minyak kelapa sawit \\
\hline Pohon karet & Getah karet & Produk olahan karet \\
\hline
\end{tabular}

Sumber: PSAK 69 (2015, par 4)

\section{Nilai Wajar}

Nilai wajar merupakan salah satu metode pengukuran aset atau liabilitas yang berdasarkan harga pasar. Menurut Pernyataan Standar Akuntansi Keuangan No. 68 tentang pengukuran nilai wajar (2016, paragraf 9), nilai wajar memiliki definisi sebagai harga yang akan diterima untuk menjual suatu aset atau harga yang akan dibayar untuk mengalihkan suatu liabilitas dalam transaksi teratur antara pelaku pasar pada tanggal pengukuran (Ikatan Akuntan Indonesia, 2016).

Sedangakan adapula pengertian lain dari nilai wajar adalah pengukuran dengan nilai pasar yang wajar, biasanya digunakan dalam revaluasi aset tidak berwujud, properti, plant dan equipment, serta investasi dalam properti, kadang untuk kategori yang disebut aset biologis dinilai berdasarkan nilai ini (Yadiati, 2007 hlm.66). Menurut Martani dkk, (2015, hlm.436) definisi dari nilai wajar adalah jumlah suatu aset dapat dipertukarkan atau suatu liabilitas diselesaikan antara pihak yang berkeinginan dan memiliki pengetahuan memadai dalam suatu transaksi yang wajar.

Pengukuran nilai wajar biasanya digunakan untuk aset atau liabilitas tertentu. Mengukur nilai wajar perlu memperhitungkan karakteristik dari aset atau liabilitas dengan berbasis pasar untuk menentukan harga aset atau liabilitas pada tanggal pengukuran. Karakteristik dari aset atau liabilitas berupa kondisi dan lokasi aset serta pembatasan atas penjualan atau penggunaan aset, jika ada.

Nilai wajar menggunakan hierarki untuk mengkategorikan input yang dipakai dalam teknik penilaian menjadi tiga level. Input tersebut adalah asumsi yang digunakan oleh para pelaku pasar ketika mereka akan menentukan harga suatu aset atau liabilitas. Tiga level input tersebut, yaitu: Input level 1 adalah harga kuotasian (tanpa penyesuaian) dipasar aktif untuk aset atau liabilitas yang identik yang dapat diakses oleh entitaspada tanggal pengukuran. Harga yang ada dipasar aktif memberikan buktu yang paling andal terkait nilai wajar dan digunakan tanpa penyesuaian; Input level 2 yaitu input selain harga yang termasuk dalam level 1, yang dapat diobservasi untuk aset dan liabilitasnya, baik secara langsung maupun tidak langsung, pada input level ke 2 ini meliputi: 1. Harga kuotasian untuk aset dan liabilitas yang serupa di pasar aktif; 2. Harga kuotasian untuk aset dan liabilitas yang identik atau yang 
serupa di pasar yang tidak aktif; dan 3. Input selain dari harga kuotasian yang dapat diobservasi untuk aset atau liabilitas; Input level 3 ini adalah input yang tidak bisa diobservasi untuk aset atau liabilitas. Input tersebut digunakan untuk mengukur nilai wajar, sejauh input yang dapat diobservasi relevan tidak tersedia. Penggunaan input yang tidak dapat diobservasi ini memungkinkan adanya situasi terdapat sedikit, jika ada aktivitas pasar untuk aset atau liabilitas pada tanggal pengukuran. Entitas menentukan input yang tidak dapat diobservasi menggunakan informasi terbaik yang tersedia dalam kondisi.Berikut adalah tabel yang menjelaskan level dari hierarki nilai wajar beserta contohnya.

Tabel 2. Hierarki Nilai Wajar

\begin{tabular}{|c|c|c|}
\hline Level & Karakteristik & Contoh \\
\hline Level1 & $\begin{array}{ll}\text { - } & \text { Dapat diobservasi } \\
\text { - } & \text { Harga kuotasi di pasar } \\
& \text { aktif (tanpa penyesuaian) }\end{array}$ & $\begin{array}{l}\text { - Harga saham LQ45 di Bursa Efek } \\
\text { Indonesia } \\
\text { - } \begin{array}{l}\text { Harga kontrak berjangka komoditas } \\
\text { pertanian di Bursa Berjangka }\end{array}\end{array}$ \\
\hline Level 2 & $\begin{array}{l}\text { - Harga kuotasi di pasar } \\
\text { aktif untuk item yang } \\
\text { serupa } \\
\text { - Harga kuotasi untuk item } \\
\text { yang identik atau serupa, } \\
\text { tidak ada pasar aktif }\end{array}$ & $\begin{array}{l}\text { - Harga penawaran yang diberikan } \\
\text { dealer untuk sekuritas yang tidak } \\
\text { likuid dan dealer siap serta mampu } \\
\text { untuk bertransaksi }\end{array}$ \\
\hline Level 3 & $\begin{array}{ll}\text { - } & \text { Input yang tidak dapat } \\
& \text { diobservasi } \\
- & \text { Tetap diperlukan } \\
& \text { perspektif pasar }\end{array}$ & $\begin{array}{l}\text { - Data yang dihasilkan sendiri oleh } \\
\text { perusahaan } \\
\text { - Nilai yang dihasilkan dari model } \\
\text { dibuat dengan asumsi manajemen, } \\
\text { yang tidak dapat dikaitkan dengan } \\
\text { data pasar yang tersedia dan } \\
\text { teramati }\end{array}$ \\
\hline
\end{tabular}

Sumber: Martani, dkk (2015, hlm.43)

\section{METODE PENELITIAN}

Penelitian ini menggunakan metode kualitatif dan telah disesuaikan dengan paradigma intepretif dan juga telah disesuaikan dengan pendekatan etnometodologi. Penelitian akan dilakukan dengan cara mengumpulkan data melalui observasi ke lokasi penelitan pada kantor dan kebun PT. IJ yang berada di Kalimantan Selatan, setelah itu mewawancarai informan yang melakukan proses kegiatan akuntansi pada PT. IJ dan menggunakan dokumen-dokumen pendukung yang berasal dari laporan keuangan yang dibuat oleh perusahaan pada tahun 2018. Kemudian penelitian akan dilanjutkan dengan melakukan validasi data dengan cara trianggulasi sumber, dimana hal tersebut dilakukan untuk mengetahui apakah data yang telah didapat sudah valid dari berbagai sumbernya, selanjutnya, data akan dianalisis dengan menggunakan cara mereduksi data yang akan digunakan dalam penelitian, menyajikan data dalam bentuk yang lebih mudah dipahami dan dilakukan penarikan kesimpulan setelah didapatnya bukti-bukti yang cukup valid.

\section{HASIL DAN PEMBAHASAN}

\section{Perlakuan Akuntansi Aktivitas Agrikultur}

Aktivitas agrikultur merupakan jenis kegiatan operasi yang dilakukan oleh entitas untuk memanajemen transformasi biologis dan panen aset biologis, yang dimana diatur perlakuan 
akuntansinya secara khusus dalam PSAK 69 tentang agrikultur. Berdasarkan PSAK 69, aktivitas agrikultur mencakup berbagai aktivitas, salah satunya adalah kehutanan, sebagaimana tercantum dalam paragraf 6 . PT. IJ merupakan entitas yang kegiatan usahanya bergerak dalam pengusahaan hutan tanaman industri. Oleh karena itu, perlakuan akuntansi yang dilakukan oleh PT. IJ dianjurkan sesuai dengan PSAK 69 tentang agrikultur.Perlakuan akuntansi atas aktivitas agrikultur berupa langkah dari pengakuan, pengukuran, pencatatan, penyajian dan pengungkapan. Pengakuan dari aktivitas agrikultur meliputi pengklasifikasian dari suatu pos yang berupa angka dan kata dalam laporan keuangan perusahaan. Pengukuran merupakan perhitungan nilai dari suatu pos. Pencatatan berupa mencatat aktivitas yang dilakukan sebagai biaya sesuai dengan nilai yang telah diukur. Penyajian berarti menyajikan informasi dari seluruh komponen keuangan ke dalam laporan keuangan. Pengungkapan merupakan pendeskripsian dan penjelasan komponen yang tercantum dalam laporan keuangan.

\section{Pengakuan}

Perlakuan akuntansi atas aktivitas agrikultur dilakukan dengan cara mengakui hasil dari aktivitas agrikultur yang dapat berupa tanaman produktif, aset biologis dan produk agrikultur. Sehingga pengakuan aktivitas agrikultur ini dapat dikatakan sebagai tahap awal yang mempengaruhi nilai pada aset biologis.

Tabel 3. Matriks Pengakuan Aktivitas Agrikultur

\begin{tabular}{|c|c|c|}
\hline No & Berdasarkan PSAK 69 & Penerapan PT IJ \\
\hline 1 & $\begin{array}{l}\text { Entitas mengakui aset biologis atau } \\
\text { produk agrikultur jika: entitas } \\
\text { mengendalikan aset biologis sebagai } \\
\text { akibat dari peristiwa masa lalu; besar } \\
\text { kemungkinan manfaat masa depan } \\
\text { yang terkait dengan aset biologis } \\
\text { tersebut akan mengalir ke entitas.; } \\
\text { dan nilai wajar atau biaya perolehan } \\
\text { aset biologis dapat diukur secara } \\
\text { andal. }\end{array}$ & $\begin{array}{l}\text { PT. IJ mengakui tanaman yang dimilikinya } \\
\text { yaitu tanaman sengon sebagai aset biologis } \\
\text { dan tanaman karet sebagai tanaman } \\
\text { produktif yang dibagi ke dua bagian, } \\
\text { tanaman belum menghasilkan dan tanaman } \\
\text { menghasilkan. Sedangkan, PT. IJ tidak } \\
\text { mengakui produk agrikultur. }\end{array}$ \\
\hline 2 & $\begin{array}{l}\text { Aset biologis diklasifikasikan baik } \\
\text { sebagai aset biologis menghasilkan } \\
\text { maupun belum menghasilkan. Aset } \\
\text { biologis menghasilkan adalah aset } \\
\text { yang telah mencapai spesifikasi } \\
\text { untuk dipanen atau mampu } \\
\text { menghasilkan panen yang } \\
\text { berkelanjutan. }\end{array}$ & $\begin{array}{l}\text { Aset biologis yang berupa tanaman sengon } \\
\text { diklasifikasikan sebagai aset biologis yang } \\
\text { akan dipanen. Sedangkan untuk tanaman } \\
\text { produktif karet di klasifikasikan ke } \\
\text { tanaman belum menghasilkan dan tanaman } \\
\text { menghasilkan. }\end{array}$ \\
\hline
\end{tabular}

Sumber: Data diolah (2018)

PSAK 69 diatur mengenai pengakuan yang perlu dilakukan terhadap aset biologis ataupun produk agrikultur pada setiap entitas yang mengendalikan aset biologis, menerima manfaat dari aset biologis atau produk agrikultur, dan aset biologis atau produk agrikultur yang dapat diukur pada nilai wajar ataupun biaya perolehannya secara andal.

Maka dapat dikatakan bahwa PT. IJ telah menerapkan pengakuan sesuai aturan pada PSAK 69, terlihat dari entitas yang telah mengakui tanaman yang dimiliki dan dikelolanya sebagai aset biologis yaitu berupa tanaman sengon, kayu sengon itu sendiri lah yang juga menjadi produk dari tanaman sengon. Tetapi penerapan tersebut dapat dikatakan belum 
sempurna, karena hasil dari tanaman karet yang berupa getah karet masih belum diakui sebagai produk agrikultur dengan alasan terdapat kendala pada pengukuran getah karet karena getah karet itu berada di dalam pohon karet, sehingga tidak dapat dilakukannya penilaian pada getah karet tersebut. Alasan yang kedua adalah PT. IJ tidak melakukan penyimpanan persediaan pada getah karet, karena karet yang disadap sejak pagi hari langsung dijual pada siang harinya, sehingga pada akhir periode berjalan pun tidak terdapatnya nilai dari persediaan yang berupa produk agrikultur. Alasan yang ketiga adalah karena pada PSAK 69 sendiri hanya menyebutkan perlunya mengakui produk agrikultur seperti getah karet tetapi tidak diberikan penjelasan bagaimana cara mengakuinya, hal itu menyebabkan pada teori tidak dapat diterapkan ke prakteknya. Sementara untuk pengakuan dari tanaman karet diterapkan berdasarkan PSAK 16, dimana tanaman karet diakui sebagai aset tidak lancar berupa tanaman produktif, karena tanaman karet merupakan aset biologis yang mampu untuk menghasilkan panen berkelanjutan.

Selain itu, pada PSAK 69 juga menganjurkan entitas untuk melakukan pengklasifikasian terhadap aset biologisnya sebagai aset biologis yang telah menghasilkan dan aset biologis yang belum menghasilkan. Pada penerapannya, PT. IJ telah melakukan pengklasifikasian pada aset biologisnya, tanaman sengonnya masih dianggap aset biologis yang belum menghasilkan karena seluruh tanaman sengon yang dimiliki masih belum siap panen dan juga tanaman sengon itu yang dipanen berupa tanamannya karena produk dari tanaman sengon adalah kayu dari tanaman tersebut.

\section{Pengukuran}

Pengukuran atas aktivitas agrikultur dilakukan setelah melakukan pengakuan aktivitas agrikultur. Kedua hal tersebut saling bersinggungan satu sama lain karena aspek yang telah diakui tersebut perlu diketahui nilainya. Pengukuran aktivitas agrikultur sendiri dilakukan dengan menilai biaya-biaya yang telah dilakukan untuk membuka lahan perkebunan, melakukan pembibitan, merawat tanaman, hingga sampai panen.

Tabel 4. Matriks Pengukuran Aktivitas Agrikultur

\begin{tabular}{clrl}
\hline No & \multicolumn{2}{c}{ Berdasarkan PSAK 69 } & \multicolumn{2}{c}{ Penerapan PT IJ } \\
\hline 1 & $\begin{array}{l}\text { Aset biologis diukur pada saat } \\
\text { pengakuan awal dan pada setiap akhir }\end{array}$ & $\begin{array}{l}\text { Aset biologis pada tanaman sengon } \\
\text { diukur pada nilai wajarnya dikurangi } \\
\text { periode pelaporan pada nilai wajar } \\
\text { dikurangi biaya untuk menjual }\end{array}$ & $\begin{array}{l}\text { dengan biaya untuk menjual. Sementara } \\
\text { untuk tanaman produktif tidak diatur } \\
\text { dalam PSAK 69, sehingga untuk tanaman } \\
\text { karet diukur pada biaya perolehannya }\end{array}$ \\
\hline 2 & $\begin{array}{l}\text { Produk agrikultur yang dipanen dari PT. IJ tidak melakukan pengukuran pada } \\
\text { aset biologis milik entitas diukur pada } \\
\text { nilai wajar dikurangi biaya untuk } \\
\text { menjual pada titik panen }\end{array}$ & \\
\hline
\end{tabular}

Sumber: Data diolah (2018)

PT. IJ telah menerapkan pengukuran sesuai dengan yang telah diwajibkan pada PSAK 69, hal tersebut terlihat dari perusahaan telah melakukan pengukuran aset biologisnya sesuai dengan yang diatur dalam PSAK 69 yaitu menggunakan nilai wajar dikurangi dengan biaya untuk menjual. Untuk tanaman karetnya karena diakui sebagai tanaman produktif maka bagi tanaman belum menghasilkan diukur dengan biaya-biaya yang dikeluarkan hingga tanaman siap dipanen. Sementara itu, untuk pengukuran tanaman menghasilkannya menggunakan biaya perolehannya dan diamortisasi sesuai masa manfaatnya. Pengukuran tersebut dilakukan 
sesuai dengan PSAK 16 karena perusahaan mengakuinya sebagai aset tetap berupa tanaman produktif.

Selain itu, pada pengukuran PSAK 69 produk agrikultur yang dipanen entitas juga diatur agar diukur pada nilai wajar diurangi biaya untuk menjual pada titik panen tidak dilakukan oleh PT. IJ. Karena PT IJ tidak mengakui adanya produk agrikultur yang dihasilkan dari aset biologisnya maupun dari tanaman produktifnya. Sehingga pengukuran hanya dilakukan pada aset biologis yang dimiliki oleh PT. IJ. Seperti yang telah dijelaskan sebelumnya bahwa produk agrikultur yang berupa getah karet dalam kasus ini tidak dilakukan pengakuan terhadapnya membuat produk agrikultur tidak dapat diukur nilainya.

\section{Pencatatan}

Setelah aktivitas agrikultur dilakukan pengakuan dan dilakukan pengukuran, langkah selanjutnya adalah melakukan pencatatan berupa penjurnalan sebesar nilai yang telah diukur, nilai yang dimaksud adalah aktivitas dari agrikultur yang dilakukan dan juga pencatatan nilai aset biologis serta produk agrikultur, terdapat juga pencatatan dari reklasifikasi yang dilakukan dan keuntungan atau kerugian yang dialami akibat dari penggunaan nilai wajar sebagai metode pengukuran aset biologi. Proses tahapan pencatatan dilakukan sejak terjadinya biaya dikeluarkan untuk melakukan aktivitas agrikultur yang berarti saat persiapan lahan untuk tanaman, penanaman, perawatan, sampai pada siap dipanen.

Tabel 5. Perbandingan Jurnal Rekomendasi PSAK 69 dengan PT IJ

\begin{tabular}{|c|c|c|c|c|c|}
\hline \multirow{2}{*}{$\begin{array}{l}\text { No } \\
1\end{array}$} & \multirow{2}{*}{$\begin{array}{c}\text { Jenis } \\
\text { Aktivitas } \\
\text { Opertasional } \\
\text { Persiapan } \\
\text { lahan untuk } \\
\text { penanaman } \\
\text { tanaman baru }\end{array}$} & \multicolumn{2}{|c|}{$\begin{array}{c}\text { Rekomendasi Jurnal PSAK } \\
69\end{array}$} & \multicolumn{2}{|c|}{ Jurnal PT IJ } \\
\hline & & $\begin{array}{c}\text { Biaya perataan tanah } \\
\text { Kas/Utang usaha }\end{array}$ & $\mathrm{xxx}$ & $\begin{array}{l}\text { Pembukaan Tanaman } \\
\text { Manual } \\
\text { xxx } \\
\text { Bank/Utang Usaha }\end{array}$ & $\begin{array}{l}\text { Baru } \\
\text { xxx }\end{array}$ \\
\hline 2 & $\begin{array}{l}\text { Ketika harga } \\
\text { perolehan dari } \\
\text { aset biologis } \\
\text { sama besar } \\
\text { dengan nilai } \\
\text { wajar } \\
\end{array}$ & $\begin{array}{l}\text { Aset Biologis belum } \\
\text { dewasa/dewasa }\end{array}$ & $\mathrm{xxx}$ & \multicolumn{2}{|l|}{ N/A } \\
\hline 3 & $\begin{array}{l}\text { Ketika harga } \\
\text { perolehan dari } \\
\text { aset biologis } \\
\text { lebih besar } \\
\text { daripada nilai } \\
\text { wajar }\end{array}$ & $\begin{array}{l}\text { Aset Biologis belum } \\
\text { dewasa/dewasa } \\
\qquad x x x \\
\text { Kerugian atas penilaia } \\
\text { Biologis } \\
\text { Xxx } \\
\text { Kas }\end{array}$ & Axx & \multicolumn{2}{|l|}{ N/A } \\
\hline 4 & $\begin{array}{l}\text { Ketika harga } \\
\text { perolehan dari } \\
\text { aset biologis } \\
\text { lebih rendah } \\
\text { dari nilai } \\
\text { wajarnya }\end{array}$ & $\begin{array}{l}\text { Aset Biologis belum } \\
\text { dewasa/dewasa } \\
\qquad \text { xxx } \\
\text { Kas } \\
\text { Laba atas penilaian } \\
\text { Biologis }\end{array}$ & $\begin{array}{r}x x x \\
\text { Aset } \\
\text { xxx }\end{array}$ & \multicolumn{2}{|l|}{ N/A } \\
\hline
\end{tabular}




\begin{tabular}{|c|c|c|c|c|c|c|}
\hline \multirow[t]{4}{*}{5} & \multirow{4}{*}{$\begin{array}{l}\text { Pembayaran } \\
\text { gaji tenaga } \\
\text { kerja langsung }\end{array}$} & \multirow{4}{*}{$\begin{array}{l}\text { Biaya TKL } \\
\text { Kas/Utang usaha }\end{array}$} & \multirow{2}{*}{$\mathrm{xxx}$} & \multicolumn{2}{|c|}{ RA - Pemeliharaan TBM } & \multirow[t]{2}{*}{$\mathrm{xxx}$} \\
\hline & & & & Hutang Gaji & $\mathrm{xxx}$ & \\
\hline & & & $\mathrm{xxx}$ & Hutang Gaji & $\mathrm{xxx}$ & \\
\hline & & & & Bank/Utang Usaha & $\mathrm{XxX}$ & \\
\hline \multirow[t]{3}{*}{6} & \multirow{3}{*}{$\begin{array}{c}\text { Pembelian } \\
\text { bahan } \\
\text { perlengkapan }\end{array}$} & \multirow{3}{*}{ Biaya perlengkapan } & \multirow[b]{2}{*}{$\mathrm{xxx}$} & Persediaan Logistik / & Bahan & \multirow{3}{*}{$\mathrm{xxx}$} \\
\hline & & & & Material & & \\
\hline & & & $\mathrm{xxx}$ & Bank/Utang Usaha & $\mathrm{xxx}$ & \\
\hline \multirow[t]{2}{*}{7} & \multirow{2}{*}{$\begin{array}{c}\text { Biaya } \\
\text { perawatan } \\
\text { rutin sebelum } \\
\text { usia produktif } \\
\text { tanaman }\end{array}$} & Biaya Pemeliharaan & $\mathrm{xxx}$ & \multicolumn{3}{|c|}{ RA - Pemeliharaan TBM 0xxx } \\
\hline & & Kas/Utang usaha & $\mathrm{xxx}$ & Bank/Utang Usaha & $\mathrm{xxx}$ & \\
\hline \multirow[t]{3}{*}{8} & \multirow{3}{*}{$\begin{array}{l}\text { Ada kecacatan } \\
\text { pada TBM }\end{array}$} & & & \multirow{2}{*}{\multicolumn{3}{|c|}{$\begin{array}{l}\text { RA - Pemeliharaan TBM (lain- } \\
\text { lain) }\end{array}$}} \\
\hline & & & XXX & & & \\
\hline & & Kas/Utang usaha & $\mathrm{xxx}$ & Bank/Utang Usaha & $\mathrm{xxx}$ & \\
\hline \multirow[t]{2}{*}{9} & \multirow[t]{2}{*}{$\begin{array}{l}\text { Ada kerusakan } \\
\text { pada TBM }\end{array}$} & $\begin{array}{l}\text { Biaya Kerugian } \\
\text { xxx }\end{array}$ & & \multicolumn{2}{|l|}{ Beban Perawatan } & $\mathrm{xxx}$ \\
\hline & & Kas/Utang usaha & $\mathrm{XXX}$ & Bank/Utang Usaha & XXX & \\
\hline
\end{tabular}

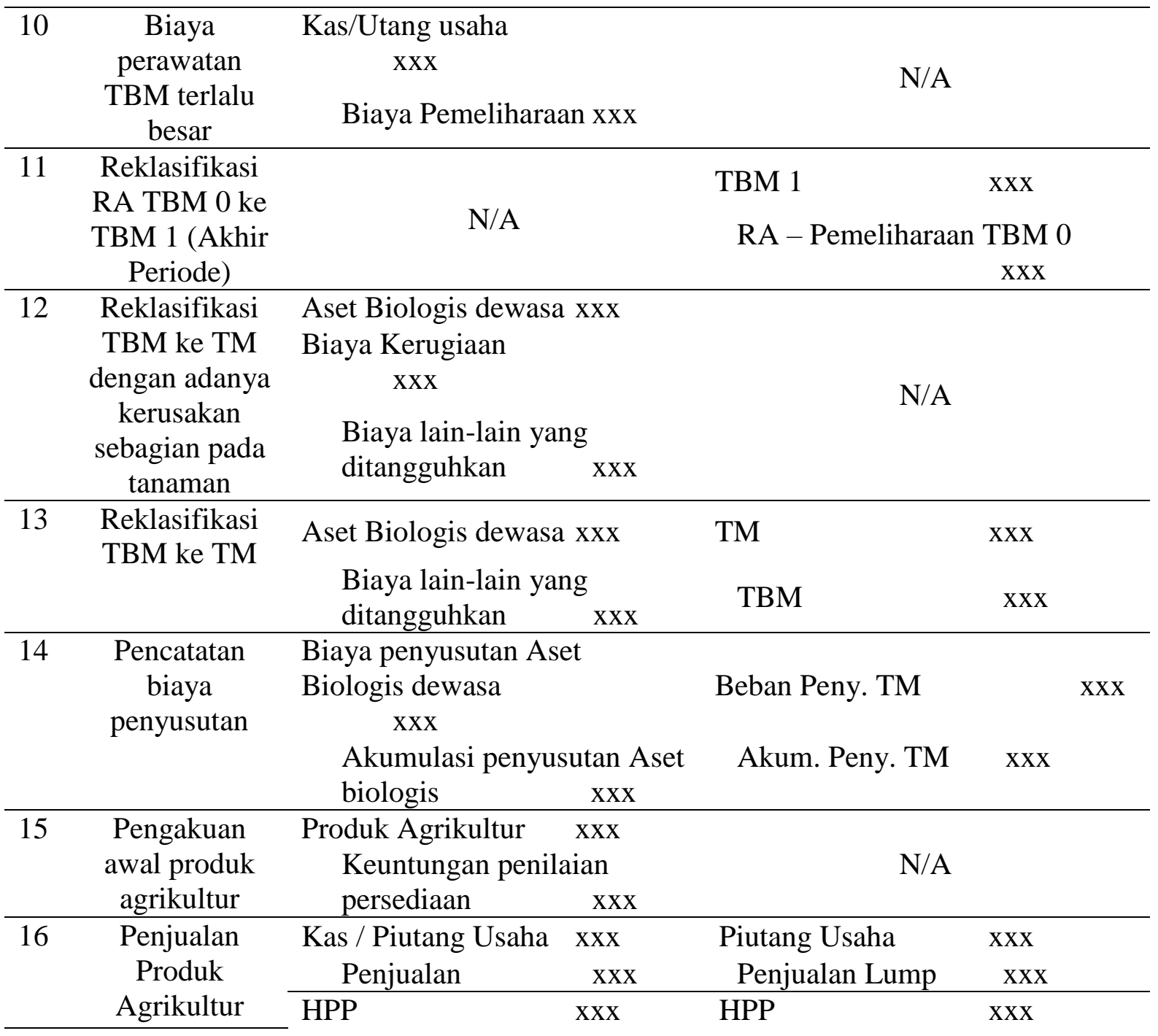




\begin{tabular}{|c|c|c|c|c|c|}
\hline & & Persediaan & $\mathrm{xxx}$ & Biaya Panen/sadap & $\mathrm{xxx}$ \\
\hline \multirow[t]{2}{*}{17} & $\begin{array}{c}\text { Pencatatan } \\
\text { nilai wajar } \\
\text { pada tanggal }\end{array}$ & $\begin{array}{c}\text { Aset Biologis belum } \\
\text { dewasa/dewasa } \\
\text { Xxx }\end{array}$ & & Aset Biologis & $\mathrm{xxx}$ \\
\hline & $\begin{array}{l}\text { neraca lebih } \\
\text { tinggi daripada } \\
\text { nilai wajar } \\
\text { yang tercatat }\end{array}$ & $\begin{array}{l}\text { Laba atas penilaia } \\
\text { Biologis belum } \\
\text { dewasa/dewasa }\end{array}$ & Aset & \multicolumn{2}{|c|}{$\begin{array}{l}\text { Laba atas Penilaian Wajar Aset } \\
\text { Biologis }\end{array}$} \\
\hline \multirow[t]{2}{*}{18} & $\begin{array}{c}\text { Pencatatan } \\
\text { nilai wajar } \\
\text { pada tanggal }\end{array}$ & \multicolumn{2}{|c|}{$\begin{array}{l}\text { Rugi atas penilaian Aset } \\
\text { Biologis belum dewasa/dewasa } \\
\quad \text { xxx }\end{array}$} & $\begin{array}{l}\text { Rugi atas Penilaian W } \\
\text { Biologis } \quad \text { xxx }\end{array}$ & Iajar Aset \\
\hline & $\begin{array}{l}\text { neraca lebih } \\
\text { rendah } \\
\text { daripada nilai } \\
\text { wajar yang } \\
\text { tercatat }\end{array}$ & $\begin{array}{l}\text { Aset Biologis belum } \\
\text { dewasa/dewasa }\end{array}$ & $\mathrm{xxx}$ & Aset Biologis & $\mathrm{xxx}$ \\
\hline
\end{tabular}

Sumber: Pratiwi (2017) dan General Ledger PT IJ (2018)

PT. IJ membuat jurnalnya sesuai dengan aktivitas yang dilakukan olehnya. Karena tidak diatur dalam PSAK 69 maka jurnal dibandingkan dengan jurnal yang direkomendasikan berdasarkan dengan hal-hal yang diatur dalam PSAK 69. Jika terdapat perbedaan dalam penjurnalan yang dilakukan hal itu karena sesuai dengan keputusan dari manajemen untuk menggunakan nama akun yang cocok bagi mereka. Perbedaan pada nama akun yang terjadi tidak mempengaruhi pengakuan terhadap akun yang ada disetiap aktivitas. Terdapat beberapa aktivitas yang tidak dilakukan penjurnalan oleh PT. IJ hal itu diakibatkan karena perusahaan belum mengalami kejadian tersebut, sehingga tidak dilakukan penjurnalan. Sebagai contoh adalah pada jenis aktivitas operasional pengakuan awal produk agrikultur PT. IJ yang tidak melakukan pengakuan terhadap produk agrikultur, maka tidak terdapat penjurnalan yang mereka lakukan.

Sementara, untuk penjualan dari produk agrikultur sendiri langsung dilakukan pada hari yang sama saat panen dilakukan, sehingga pencatatan pada persediaan tidak dilakukan dan untuk nilai pada harga pokok penjualan didapatkan dari nilai biaya yang dikeluarkan untuk melakukan panenSelain itu, karena pencatatan jurnal tidak diatur pada PSAK 69 maka selama nilai dari aktivitas agrikultur dan aset biologis serta produk agrikultur diakui, diukur dan dicatat sesuai dengan yang terjadi akan membuat pencatatan nilai aktivitas agrikultur tersajikan dengan wajar.

\section{Penyajian Dan Pengungkapan}

Proses penyajian dan pengungkapan atas aktivitas agrikultur dalam laporan keuangan berupa nilai dari aset biologis dan tanaman produktif, Hal ini karena aktivitas yang telah dilakukan oleh perusahaan merupakan langkah untuk memberikan manfaat kepada aset biologis dan tanaman produktif. Selain itu, aktivitas agrikultur merupakan biaya yang dikeluarkan dan seperti yang dijelaskan sebelumnya besaran nilai biaya tersebut dialokasikan kepada nilai dari aset biologis dan tanaman produktif.

Tabel 6. Matriks Penyajian dan Pengungkapan Aktivitas Agrikultur

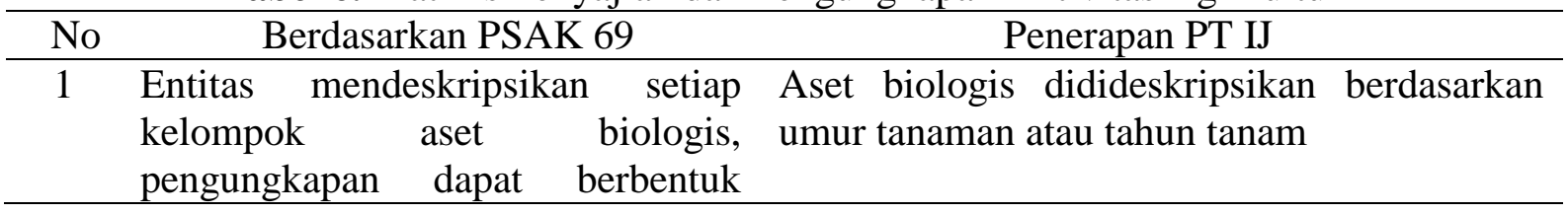




\begin{tabular}{ll}
\hline \multicolumn{1}{l}{ deskripsi naratif atau kuantitatif } \\
\hline 2 & $\begin{array}{l}\text { Entitas menyajikan rekonsiliasi } \\
\text { perubahan jumlah tercatat aset }\end{array}$ \\
biologis antara awal dan akhir \\
periode berjalan
\end{tabular}

Sumber: Data diolah (2018)

PT. IJ telah menerapkan penyajian dan juga pengungkapan atas aktivitas agrikultur sesuai dengan yang diatur di dalam PSAK 69. Hal tersebut terlihat pada Gambar 8. Pendeskripsian dan Rekonsiliasi Aset biologis, yang menunjukkan bahwa aset biologis yang dimiliki oleh PT. IJ dideskripsikan baik itu berbentuk deskripsi naratif atau kuantitatif yang dikelompokkan berdasarkan tahun tanam dari aset biologis yang berupa tanaman sengon. Penerapan tersebut sesuai dengan yang diinstruksikan pada PSAK 69 untuk memberikan pendeskripsian terhadap setiap kelompok aset biologis entitas.

Selain itu, pada PSAK 69 juga diatur untuk melakukan penyajian terhadap rekonsiliasi perubahan jumlah tercatat aset biologis antara awal periode dan akhir periode berjalan. Hal yang telah diatur tersebut telah dilakukan oleh PT. IJ dengan melakukan penyajian atas mutasi dari aset biologisnya dimana hal tersebut mengungkapkan perubahan nilai dari jumlah aset biologis yang tercatat antara awal dan akhir periode berjalannya.

Terdapat pula hal lain yang diatur pada PSAK 69, yaitu mengenai keuntungan ataupun kerugian yang terjadi pada pengakuan awal dari aset biologis pada nilai wajarnya dikurangi biaya untuk menjual dan dari perubahan nilai wajar aset biologis untuk dimuat dalam laba atau rugi dimana keuntungan atau kerugian tersebut terjadi. PT. IJ telah mengakui keuntungan yang didapat dari pengakuan awal dan dari perubahan nilai wajar aset biologis. Hal tersebut disajikan pada laporan laba rugi perusahaan dalam beban usaha lainnya dan diungkapkan pada rincian beban usaha lainnya yang mencatatkan laba atas nilai wajar aset biologis.

\section{SIMPULAN}

Hasil penelitian yang dilakukan pada PT. IJ memberikan kesimpulan bahwa perlakuan akuntansi atas aktivitas agrikultur dapat dikatakan telah sesuai berdasarkan dengan yang dianjurkan pada PSAK 69. Kesesuaian dilihat dari setiap perlakuan akuntansi yang diatur sebagai berikut:

1. Proses pengakuan aktivitas agrikultur pada PT. IJ telah dilakukan berdasarkan dengan PSAK 69, namun dapat dikatakan masih belum sempurna. Pengakuan untuk tanaman sengon telah dilakukan sesuai PSAK 69, sementara untuk tanaman karet menggunakan PSAK 16. Produk agrikultur berupa getah karet tidak diakui ke dalam persediaan karena perusahaan tidak melakukan penyimpanan persediaan getah karet, seperti yang telah dijelaskan sebelumnya.

2. Pada PT. IJ, proses pengukuran aktivitas agrikultur dilakukan berdasarkan biaya yang telah dikeluarkan untuk melakukan kegiatan tersebut. Pengukuran menggunakan biaya 
perolehan untuk menentukan nilai tanaman karet dan menggunakan nilai wajar bagi tanaman sengon. Namun PT. IJ belum mengukur produk agrikultur yang dihasilkannya yaitu getah karet.

3. Proses Pencatatan aktivitas agrikultur pada PT. IJ dilakukan berdasarkan dengan kegiatan yang dilakukan dan sesuai dengan nilai yang diakui dan telah diukur serta penjurnalan terhadap aktivitas yang dilakukan dimasukkan kedalam running account sebelum diatribusikan kepada tanaman.

4. PT. IJ telah menentukan nilai wajar pada aset biologisnya dengan menggunakan pendekatan harga jual per meter kubik dikurangi dengan estimasi biaya penjualan saat panen dan estimasi biaya perawatan sampai dengan panen, tetapi nilai wajar baru diterapkan pada tanaman yang umurnya lebih dari 2 tahun. Sementara untuk tanaman dibawah 2 tahun menggunakan pendekatan biaya perolehan.

5. Penyajian dan pengungkapan atas aktivitas agrikultur pada PT. IJ disajikan dalam bentuk deskripsi kelompok aset biologis, mutasi tanaman dan keuntungan atau kerugian yang timbul selama periode berjalan pada saat pengakuan awal dan perubahan nilai wajar aset biologis.

\section{DAFTAR PUSTAKA}

Afrizal. (2014). Metode Penelitian Kualitatif: Sebuah Upaya Mendukung Penggunaan Penelitian Kualitatif dalam Berbagi Disiplin Ilmu. Jakarta: PT Rajagrafindo Persada.

Ahmadi, R. (2014). Metode Penelitian Kualitatif. Yogyakarta: Ar-Ruzz Media.

Darmayasa, I. N., \& Aneswari, Y. R. (2015). Penelitian Akuntansi Interpretif di Indonesia. Jurnal Akuntansi Multiparadigma, 6(3), 350-361.

Feleagă, L., Feleagă, N., \& Răileanu, V. (2012). Theoretical considerations about implementation of IAS 41 in Romania. Theoretical and Applied Economics Volume, $X I X(2), 31-38$.

Gonçalves, R., \& Lopes, P. (2015). Accounting in Agriculture: Measurement Practices of Listed Firms. FEP Working Papers, (530), 1-34.

Hidayat, M. (2018). Analisis Perlakuan Akuntansi Aktivitas Agrikultur Pada Perusahaan Sektor Perkebunan yang Terdaptar Di BEI Menjelang Penerapan PSAK 69. Measurement, 12(1), 36-52.

Ikatan Akuntan Indonesia. (2015). Pernyataan Standar Akuntansi Keuangan: Agrikultur. Jakarta: Ikatan Akuntan Indonesia.

Ikatan Akuntan Indonesia. (2016). Standar Akuntansi Keuangan: Efektif per 1 Januari 2017. Jakarta: Ikatan Akuntan Indonesia.

Indrawati. (2018). Metode Penelitian Kualitatif: Manajemen dan Bisnis Konvergensi Teknologi Informasi dan Komunikasi. Bandung: PT Refika Aditama.

International Accounting Standards Board. (2016). IAS 41. London: International Accounting Standards Board.

Kurniawan, A. (2019). Neraca Perdagangan Pertanian Indonesia 2018 Surplus Rp 139,6 Triliun. Retrieved February 15, 2019, from https://ekonomi.kompas.com/read/2019/02/09/142641226/neraca-perdaganganpertanian-indonesia-2018-surplus-rp-1396-triliun

Martani, D., Siregar, S. V., Wardhani, R., Farahmita, A., Tanujaya, E., \& Hidayat, T. (2015). Akuntansi Keuangan Menengah Berbasis PSAK. Jakarta: Salemba Empat.

Nurhayat, W. (2018). Pekerja di Sektor Pertanian Indonesia Terus Berkurang. Retrieved February 15, 2019, from https://kumparan.com/@kumparanbisnis/pekerja-di-sektorpertanian-indonesia-terus-berkurang-1541405969905898718 
Pratiwi, W. (2017). Analisis Perlakuan Akuntansi Aset Biologis Berbasis Psak-69 Agrikultur Pada Pt.Perkebunan Nusantara Xii Kalisanen Kabupaten Jember. Prosiding Seminar Nasional Dan Call For Paper Ekonomi Dan Bisnis (SNAPER-EBIS 2017) -, 2017, $140-150$.

Raco, J. R. (2010). Metode Penelitian Kualitatif: Jenis, Karakteristik dan Keunggulannya. Jakarta: PT Gramedia Widiasarana Indonesia.

Setiyawan, D. (2018). Perlakuan Akuntansi Aset Biologis PT Perkebunan Nusantara XII Kebun Bantaran Blitar. Simki-Economic, 02(01).

Sugiyono. (2016). Memahami Penelitian Kualitatif. Bandung: Alfabeta.

Sutedja. (2006). Pengungkapan ( Disclosure ) Laporan Keuangan Sebagai Upaya Mengatasi Asimetri Informasi. Jurnal Infestasi, 3(2), 113-125.

Suwardjono. (2010). Teori Akuntansi: Perekayasaan Pelaporan Keuangan (Ketiga). Yogyakarta: BPFE-Yogyakarta.

Wulandari, R., \& Wijayati, F. L. (2018). Analisis Perlakuan Akuntansi Aset Biologis Pada Perusahaan Sektor Agrikultur Subsektor Perkebunan Yang Terdaftar Di Bursa Efek Indonesia (BEI). Riset Akuntansi Dan Keuangan Indonesia, 3(2), 139.

Yadiati, W. (2007). Teori Akuntansi: Suatu Pengantar (Pertama). Jakarta: Prenadamedia Group.

Yefni, Arifulsyah, H., \& Nurulita, S. (2018). An Analysis of the Implementation of PSAK 69 at PT Perkebunan Nusantara V ( Persero ). Accounting Finance Review, 3(1), 53-61.

Yusuf, M. (2014). Metode Penelitian: Kuantitatif, Kualitatif, dan Penelitian Gabungan. Jakarta: Prenadamedia Group.

Copyright (c) 2020 Fathi Maurits Muhamada 